Erratum

\title{
Erratum: Norman C. Treloar. Deconstructing Global Temperature Anomalies: An Hypothesis. Climate $2017,5,83$
}

\section{Climate Editorial Office}

MDPI, St. Alban-Anlage 66, 4052 Basel, Switzerland; Tel.: +41-61-683-7734

Received: 7 May 2018; Accepted: 10 May 2018; Published: 11 May 2018

The authors would like to correct Section 1.2 of this article [1] as follows:

The error occurs on page 3 of the PDF, 7 lines down in Section 1.2. The text currently incorrectly runs " 18.847 and 18.613 ". It should read " $1,8.847$ and 18.613 ", so there should be three numbers there, not two.

We apologize for any inconvenience caused to the readers by this mistake.

\section{Reference}

1. Treloar, N.C. Deconstructing Global Temperature Anomalies: An Hypothesis. Climate 2017, 5, 83. [CrossRef]

(C) 2018 by the author. Licensee MDPI, Basel, Switzerland. This article is an open access article distributed under the terms and conditions of the Creative Commons Attribution (CC BY) license (http:/ / creativecommons.org/licenses/by/4.0/). 